\title{
KONTRIBUSI PENDAPATAN ASLI DAERAH TERHADAP PENERIMAAN PEMERINTAH DAERAH KABUPATEN TAKALAR
}

\author{
Buyung Romadhoni ${ }^{1}$, Akhmad ${ }^{2}$, Amir $^{3}$ \\ ${ }^{123}$ Fakultas Ekonomi dan Bisnis Universitas Muhammadiyah Makassar \\ buyung@unismuh.ac.id ${ }^{1}$, akhmad.pide@unismuh.ac.id², amir@unismuh.ac.id ${ }^{3}$
}

\begin{abstract}
In the current era of regional autonomy, it is hoped that local revenue is the main source of revenue from regional revenues, but in fact the contribution of Regional Original Income to total regional revenue is still relatively small, as well as showing that the financial independence of regional governments is relatively small. Therefore this study aims to; knowing the contribution of each regional tax variable, regional levies, the results of separated regional wealth management; etc. The legal revenue from the region to the original regional income in Takalar Regency and knowing the contribution of the original regional income to the total revenue of the Takalar Regency regional government. This study uses secondary data sourced from the Directorate General of Fiscal Balance, Ministry of Finance of the Republic of Indonesia and the Government of Takalar Regency. 2010 to 2020. The results of the study show that local taxes and other legitimate local revenues have a significant contribution to the regional revenue of Takalar district. The results also show that the contribution of own-source revenue to total regional income is still relatively small, but the trend of increasing contribution tends to increase from year to year.
\end{abstract}

Keywords: Local Revenue; Contribution; Regional Revenue

\begin{abstract}
ABSTRAK
Dalam era otonomi daerah dewasa ini, pendapatan asli daerah diharapkan menjadi sumber penerimaan utama dari penerimaan daerah, namun pada kenyataanya kontribusi Pendapatan Asli Daerah terhadap total penerimaan daerah relatif masih kecil, sekaligus menunjukkan bahwa kemandirian keuangan pemerintah daerah relatif kecil. Oleh karena itu penelitian ini bertujuan untuk; mengetahui kontribusi masing-masing variabel pajak daerah, retribusi daerah, hasil pengelolaan kekayaan daerah yang dipisahkan; dan lain-lain pendapatan asli daerah yang sah terhadap pendapatan asli daerah di Kabupaten Takalar dan mengetahui kontribusi pendapatan asli daerah terhadap total penerimaan pemerintah daerah Kabupaten Takalar. Penelitian ini menggunakan data sekunder yang bersumber dari Direktorat Jenderal Perimbangan Keuangan Kementerian Keuangan Republik Indonesia dan Pemerintah Kabupaten Takalar tahun 2010 sampai tahun 2020. Hasil penelitian menunjukkan bahwa pajak daerah dan dan lain-lain pendapatan asli daerah yang sah memiliki kontribusi yang cukup besar terhadap pendapatan asli daerah kabupaten Takalar. Hasil penelitian juga menunjukkan bahwa kontribusi pendapatan asli daerah terhadap total pendapatan daerah relatif masih kecil, tetapi tren peningkatan kontribusi cenderung meningkat dari tahun ke tahun.
\end{abstract}

Kata kunci: Pendapatan asli daerah; Kontribusi; Penerimaan Daerah 


\section{PENDAHULUAN}

Salah satu ciri dari sistem pemerintahan yang demokratis adalah memberikan ruang bagi rakyat luas untuk berpartisipasi dalam hal mempengaruhi proses pengambilan kebijakan oleh pemerintah, melalui saluran-saluran demokrasi yang tersedia (Stiglitz J.E and J.K.Rosengard， 2015). Implementasi demokrasi didasari atas kehendak menjadikan kekuasaan tidak bersifat absolut pada satu pengambilan keputusan saja. Demokrasi menginginkan bahwa keputusan mengenai satu kebijakan merepresentasikan suara dan kepentingan banyak pihak. Sebab kekuasaan dalam satu tangan cenderung menciptakan otoritarianisme (Cullis, J.G. and P.R. Jones., 1992). Oleh karena itu, desentralisasi kekuasaan menjadi satu keharusan dalam sistem demokrasi. Desentralisasi kekuasaan selain terlihat dari pembagian kekuasaan dalam model trias politica, juga dilaksanakan dalam bentuk hubungan kekuasaan antara pemerintah pada tingkat pusat dan daerah, dimana otoritas pemerintahan terdistribusi pada pemerintahan tingkat lokal. Pemerintah lokal memiliki wewenang menjalankan roda pemerintahan di wilayahnya (Samimi A.J at al, 2010). Kewenangan inilah yang dinamakan dengan local discretion.

Undang-undang No. 32 Tahun 2004 tentang otonomi daerah, memberikan kewenangan kepada pemerintah daerah daerah untuk mengatur dan mengelola daerahnya masing-masing. Oleh karena itu pemerintah daerah sebagai administrator penuh terhadap daerahnya, harus dapat memanfaatkan segenap sumber daya yang ada di daerahnya sebagai upaya untuk meningkatkan kesejahteraan masyarakat daerahnya.

Bagaimanapun, otonomi daerah merupakan kewenangan untuk membuat kebijakan (mengatur) dan melaksanakan kebijakan (mengurus) berdasarkan perkara sendiri, (Akhmad at.al, 2013). Sehingga, masyarakat yang berada pada satu teritori tertentu adalah pemilik dan subyek Otonomi daerah. Hal ini, membawa konsekuensi perlunya partisipasi aktif dari masyarakat dalam setiap tahap penyelenggaraan otonomi, (Mardiasmo, 2009).

Desentralisasi fiskal ditandai dengan meningkatnya alokasi dana transfer dari pemerintah pusat ke pemerintah daerah (dana perimbangan), berupa: (1) peningkatan persentase dana bagi hasil (DBH) untuk pemerintah daerah, (2) peningkatan dana alokasi umum (DAU), dan (3) pelimpahan dana 
alokasi khusus (DAK), (Safrianto $\mathrm{S}$, pendapatan pemerintah atau instansi lebih 2017). Desentralisasi fiskal juga haruslah tinggi, hal ini menunjukkan didukung oleh sumber-sumber keuangan ketergantungan yang sangat besar dari yang memadai baik berasal dari daerah itu pemerintah daerah terhadap pemerintah sendiri yang dikenal Pendapatan Asli daerah (PAD, (Sabilla K \& W.K.Jaya, 2014).

Pendapatan Asli daerah sebagai upaya nyata dari pemerintah dalam memperoleh penghasilan, merupakan salah satu indikator utama dalam melihat tingkat kemandirian pemerintah daerah dalam bidang keuangan, (Yanti N., 2013). Karena itu pemerintah pusat senantiasa mendorong pemerintah daerah dalam meningkatkan pendapatan asli daerahnya baik dalam bentuk pajak daerah, retribusi daerah, hasil pengelolaan kekayaan daerah yang dipisahkan; dan lain-lain PAD yang sah terhadap pendapatan asli daerah, (Akhmad, 2015).

Pendapatan Asli Daerah (PAD) memiliki peran yang sangat penting dalam menentukan kemampuan daerah untuk melakukan aktivitas pemerintahan dalam melaksanakan program pembangunan di daerahnya. Akan tetapi pada kenyataannya banyak daerah yang memiliki struktur kontribusi PAD relatif kecil terhadap total penerimaan daerah, sebaliknya sebagian penerimaan pendapatan terbesar justru berasal dari pusat, (Firdausy C.M, 2017).

Tantangan utama yang dihadapi oleh pemerintah daerah dewasa ini yaitu terbatasnya sumber keuangan yang diperoleh oleh pemerintah daerah yang bersumber dari pendapatan asli daerah (PAD). Hasil penelitian (Akhmad dkk, 2020) menunjukkan bahwa kontribusi, PAD terhadap total penerimaan pemerintah daerah di Provinsi Sulawesi Selatan relatif kecil. Oleh karena itu penulis tertarik untuk lebih mendalami kontribusi Pendapatan Asli Daerah terhadap total penerimaan pemerintah daerah, dengan melakukan penelitian secara mendalam di Kabupaten Takalar.

Oleh karena itu penelitian bertujuan (1) mengetahui kontribusi masing-masing variabel pendapatan asli daerah yaitu pajak daerah, retribusi daerah, hasil pengelolaan kekayaan daerah yang dipisahkan; dan lain-lain PAD yang sah terhadap pendapatan asli daerah di Kabupaten Takalar dan (2) mengetahui kontribusi pendapatan asli daerah terhadap total penerimaan pemerintah daerah Kabupaten Takalar. 


\section{TINJAUAN PUSTAKA}

\section{Konsep Keuangan Daerah}

Keuangan daerah sebagaimana yang dimuat dalam penjelasan pasal 156 ayat 1 Undang-Undang Nomor 32 Tahun 2004 tentang pemerintahan daerah dikatakan bahwa Keuangan daerah adalah semua hak dan kewajiban daerah yang dapat dinilai dengan uang dan segala sesuatu berupa uang dan barang yang dapat dijadikan milik daerah yang berhubungan dengan pelaksanaan hak dan kewajiban tersebut. Dengan pemikiran, maka keuangan daerah tersebut, pada dasarnya menekankan pada dua hal pokok yaitu tentang hak dan kewajiban pemerintah daerah yang terkait dengan keuangan daerah, (Akhmad,, 2019).

Pemerintah daerah dalam rangka keuangan daerah adalah segala hak yang melekat pada daerah sesuai dengan peraturan perundang-undangan yang digunakan dalam usaha pemerintah daerah mengisi kas daerah. Hak pemerintah Daerah tersebut meliputi antara lain: (1) hak menarik pajak daerah, (2) hak untuk menarik retribusi/iuran daerah (3) hak mengadakan pinjaman, dan (4) hak untuk memperoleh dana perimbangan dari pusat, (Peraturan pemerintah RI No.12 Tahun, 2019). Seluruh penerimaan pemerintah daerah dan pengeluaran pemerintah daerah harus dicatat dan dikelola dalam Anggaran Pendapatan dan Belanja Daerah, (Direktorat Jenderal Perimbangan keuangan,, 2017).

Anggaran Pendapatan dan Belanja Daerah merupakan dasar pengelolaan keuangan daerah dalam satu tahun anggaran. APBD merupakan rencana pelaksanaan semua pendapatan daerah dan semua belanja daerah dalam rangka pelaksanaan desentralisasi dalam tahun anggaran tertentu. Pemungutan semua penerimaan daerah bertujuan untuk memenuhi target yang ditetapkan dalam APBD. Demikian pula semua pengeluaran daerah dan ikatan yang membebani daerah dalam rangka pelaksanaan desentralisasi dilakukan sesuai jumlah dan sasaran yang ditetapkan dalam APBD. Karena APBD merupakan dasar pengelolaan keuangan daerah, maka APBD menjadi dasar pula bagi kegiatan pengendalian, pemeriksaan dan pengawasan keuangan daera, (Savitri K.A.dkk, 2019).

Pendapatan daerah meliputi semua penerimaan uang melalui Rekening Kas Umum Daerah, yang menambah ekuitas dana lancar, yang merupakan hak daerah dalam satu tahun anggaran yang tidak perlu dibayar kembali oleh Daerah. Pendapatan daerah terdiri atas: (1) Pendapatan Asli Daerah (PAD); (2) Dana 
perimbangan, yang terdiri atas Dana bagi hasil (DBH), dana alokasi Umum (DAU), dan Dana Alokasi Khusus (DAK) (3) dan Lain-lain pendapatan daerah yang sah, (UU No.33 Tahun, 2004).

\section{Pendapatan Asli Daerah}

Pendapatan Asli Daerah (PAD) adalah penerimaan yang diperoleh daerah dari sumber-sumber yang ada di wilayahnya sendiri, yang dipungut berdasarkan Peraturan Daerah (PERDA). PAD diharapkan menjadi salah satu sumber pembiayaan penyelenggaraan pemerintahan dan pembangunan daerah, (Aji B.P. dkk, 2015).

Kewenangan daerah untuk memungut PAD diatur dalam UndangUndang Nomor 18 tahun 1997 sebagaimana telah disempurnakan dalam Undang-Undang Nomor 34 tahun 2000, dan selanjutnya Undang-Undang Nomor 28 tahun 2009. Undang-undang ini mencerminkan keleluasaan daerah untuk menggali sumber-sumber pembiayaan dari daerahnya sendiri seperti pajak daerah, hasil retribusi daerah, hasil perusahaan milik daerah, dan hasil pengelolaan kekayaan daerah, dan lain-lain PAD yang sah.

\section{Pajak Daerah}

Undang-Undang Nomor 28 Tahun 2009 tersebut, Pasal 1 ayat 10 dikatakan bahwa; Pajak Daerah, yang selanjutnya disebut Pajak, adalah kontribusi wajib kepada Daerah yang terutang oleh orang pribadi atau badan yang bersifat memaksa berdasarkan Undang-Undang, dengan tidak mendapatkan imbalan secara langsung dan digunakan untuk keperluan Daerah bagi sebesar-besarnya kemakmuran rakyat.

Berdasarkan undang-undang tersebut, maka daerah (baik provinsi maupun kabupaten/kota) diberikan kewenangan untuk memungut berbagai jenis pajak sebagaimana ditunjukkan pada Tabel 1. 
Tabel 1

Jenis dan Tarif Pajak Provinsi

\begin{tabular}{|c|c|}
\hline Jenis Pajak & Tarif (max) \\
\hline \multirow{2}{*}{$\begin{array}{l}\text { 1. Pajak kendaraan } \\
\text { bermotor }\end{array}$} & $1 \mathrm{~S} / \mathrm{D} 2 \%$ untuk kendaraan pertama \\
\hline & 2 s/10 \% untuk kendaraan kedua dan seterusnya \\
\hline 2. Bea balik Nama & Penyerahan pertama sebesar maksimum $20 \%$ \\
\hline Kendaraan bermotor & penyerahan kedua dan seterusnya sebesar maksimum $1 \%$ \\
\hline $\begin{array}{l}\text { 3. Pajak bahan bakar } \\
\text { kendaraan bermotor }\end{array}$ & Maksimum sebesar $10 \%$ dari nilai jual bahan bakar \\
\hline $\begin{array}{l}\text { 4. Pajak Air Permukaan; } \\
\text { dan }\end{array}$ & $\begin{array}{l}\text { Maksimum sebesar } 10 \% \text { dari nilai perolehan } 10 \% \text { dari } \\
\text { cukai rokok }\end{array}$ \\
\hline 5. Pajak Rokok & \\
\hline
\end{tabular}

Tabel 2

Jenis dan Tarif Pajak Kabupaten/Kota

\begin{tabular}{|c|c|}
\hline Jenis Pajak & Tarif (max) \\
\hline a. Pajak Hotel & - paling tinggi sebesar $10 \%$ \\
\hline b. Pajak Restoran & - paling tinggi sebesar $10 \%$ \\
\hline c. Pajak Hiburan & $\begin{array}{l}\text { - } \text { paling tinggi sebesar } 35 \% \text {. } \\
\text { - } \text { Khusus untuk Hiburan berupa pagelaran busana, kontes } \\
\text { kecantikan, diskotik, karaoke, klub malam, permainan } \\
\text { ketangkasan, panti pijat, dan mandi uap/spa, tarif Pajak } \\
\text { Hiburan dapat ditetapkan paling tinggi sebesar } 75 \%\end{array}$ \\
\hline d. Pajak Reklame & - paling tinggi sebesar $25 \%$. \\
\hline $\begin{array}{l}\text { e. Pajak Penerangan } \\
\text { Jalan }\end{array}$ & $\begin{array}{l}\text { - paling tinggi sebesar } 10 \% \text {. } \\
\text { - paling tinggi sebesar } 25 \% \text {. }\end{array}$ \\
\hline $\begin{array}{l}\text { f. Pajak Mineral Bukan } \\
\text { Logam dan Batuan }\end{array}$ & - paling tinggi sebesar $30 \%$. \\
\hline g. Pajak Parkir & - paling tinggi sebesar $20 \%$. \\
\hline h. Pajak Air Tanah & - paling tinggi sebesar $10 \%$. \\
\hline $\begin{array}{l}\text { i. Pajak Sarang Burung } \\
\text { Walet }\end{array}$ & - paling tinggi sebesar $0,3 \%$. \\
\hline $\begin{array}{ll}\text { j. } & \text { Pajak Bumi dan } \\
& \text { Bangunan Perdesaan } \\
\text { dan Perkotaan } \\
\text { k. } & \text { Bea Perolehan Hak } \\
\text { atas Tanah dan } \\
\text { Bangunan. }\end{array}$ & - paling tinggi sebesar $5 \%$. \\
\hline
\end{tabular}




\section{Retribusi Daerah}

Undang-Undang Nomor 28 Tahun 2009 tersebut, Pasal 1 ayat 64 dikatakan bahwa; Retribusi Daerah, yang selanjutnya disebut Retribusi, adalah pungutan Daerah sebagai pembayaran atas jasa atau pemberian izin tertentu yang khusus disediakan dan/atau diberikan oleh Pemerintah Daerah untuk kepentingan orang pribadi atau Badan. Selanjutnya dalam Retribusi Undang-Undang Nomor 28 Tahun 2009 Pasal 108 dikatakan bahwa objek retribusi daerah terdiri atas; (a) Jasa Umum; (b), Jasa Usaha; dan (c) Perizinan Tertentu.

Untuk beberapa daerah retribusi daerah merupakan penyumbangan terbesar terhadap pendapatan asli daerah dalam arti memberi sumbangsi lebih besar dari pada pajak daerah. Retribusi pada dasarnya merupakan pungutan yang dilakukan oleh pemerintah daerah atas pemanfaatan suatu jasa tertentu yang disediakan oleh pemerintah. Jadi dalam hal ini terdapat imbalan langsung yang diperoleh oleh pengguna retribusi. Retribusi daerah pada dasarnya dibagi atas tiga jenis yaitu; Jenis Retribusi Jasa Umum, Retribusi Jasa Usaha dan Retribusi Perizinan Tertentu.

\section{Hasil Pengelolaan Kekayaan Daerah}

\section{yang Dipisahkan}

Hasil pengelolaan kekayaan daerah yang dipisahkan sebagaimana dimaksud menurut Peraturan Menteri Dalam Negeri Nomor 21 Tahun 2011 tentang pedoman pengelolaan keuangan daerah pasal 26 huruf c dikatakan bahwa; hasil pengelolaan kekayaan daerah yang dipisahkan dirinci menurut obyek pendapatan yang mencakup:

a. bagian laba atas penyertaan modal pada perusahaan milik daerah/BUMD;

b. bagian laba atas penyertaan modal pada perusahaan milik pemerintah/BUMN; dan

c. bagian laba atas penyertaan modal pada perusahaan milik swasta atau kelompok usaha masyarakat.

\section{Pendapatan Asli Daerah Lain yang Sah}

Jenis lain-lain pendapatan asli daerah yang sah sebagaimana yang dimaksud dalam Peraturan Menteri Dalam Negeri Nomor 21 Tahun 2011 Pasal 26 huruf $\mathrm{d}$, meliputi; (a) hasil penjualan kekayaan daerah yang tidak dipisahkan; (b) jasa giro; (c) pendapatan bunga; (d) penerimaan atas tuntutan ganti kerugian daerah; (e) penerimaan komisi, potongan ataupun bentuk lain sebagai akibat dari penjualan dan/atau pengadaan barang 
dan/atau jasa oleh daerah; (f) penerimaan keuntungan dari selisih nilai tukar rupiah terhadap mata uang asing; (g) pendapatan denda atas keterlambatan pelaksanaan pekerjaan; (h) pendapatan denda pajak; (i) pendapatan denda retribusi; $(j)$ pendapatan hasil eksekusi atas jaminan;(k) pendapatan dari pengembalian; (I) fasilitas sosial dan fasilitas umum; (m) pendapatan dari penyelenggaraan pendidikan dan pelatihan; dan (n) pendapatan dari angsuran/cicilan penjual

\section{METODE PENELITIAN}

Penelitian ini dilakukan di Kabupaten Takalar dengan fokus pada kontribusi masing-masing variabel pendapatan asli daerah (Pajak daerah, retribusi daerah, Hasil Pengelolaan Kekayaan Daerah yang Dipisahkan, Pendapatan Asli Daerah Lain yang Sah) terhadap total pendapatan asli daerah dan kontribusi pendapatan asli daerah terhadap total penerimaan daerah. Oleh karena itu analisis hanya dibatasi pada objek pendapatan asli daerah dan penerimaan daerah kabupaten Takalar Provinsi Sulawesi selatan dari tahun 2010-2020.

Data yang digunakan dalam penelitian ini adalah data sekunder yang mencakup Pendapatan Asli Daerah, total pendapatan daerah, tahun 2010-2020 yang bersumber dari Direktorat Jenderal Perimbangan Keuangan Kementerian Keuangan Republik Indonesia, Badan Pusat Statistik Kabupaten Takalar, dan Pemerintah Kabupaten Takalar.

\section{Model Analisis}

Untuk mengetahui kontribusi masing-masing variabel pendapatan asli daerah terhadap total pendapatan asli daerah digunakan analisis rasio keuangan. Demikian halnya untuk mengetahui kontribusi pendapatan asli daerah terhadap total penerimaan daerah digunakan analisis rasio keuangan. Adapun rumus rasio kontibusi variabel pajak daerah terhadap pendapatan asli daerah digunakan rumus:

$$
\text { Kontribusi Variabel Pendapatan Asli Darrah }=\frac{\text { Variabel Pendapstan Asli Daerah }}{\text { Pendapatan Asli Daerah }} \times 100 \%
$$

Dimana variabel penerimaan retribusi daerah, (3) hasil pengelolaan daerah terdiri atas: (1) Pajak daerah, (2) kekayaan daerah yang dipisahkan, dan (4) 
pendapatan asli daerah lain yang sah.

Sementara kontribusi variabel digunakan rumus: pemerintah daerah Kabupaten Takalar

pajak daerah terhadap total penerimaan

Kontribusi PendapatanAsliDaerah $=\frac{\text { PendapaanAsli Daerah }}{\text { Tinfal Penerimann Pammintah Daprah }} \times 100 \%$

\section{HASIL PENELITIAN DAN PEMBAHASAN}

\section{Gambaran Umum Kabupaten Takalar}

Secara geografis Kabupaten

Takalar terletak di bagian selatan Provinsi

Sulawesi Selatan dengan jarak $40 \mathrm{~km}$ dari

Kota Metropolitan Makassar, dengan batas wilayah Kabupaten Takalar sebagai berikut: Sebelah Utara dengan kota Makassar dan Kabupaten Gowa, Sebelah Selatan dengan Laut Flores, Sebelah Barat dengan Selat Makassar, Sebelah Timur dengan Kabupaten Jeneponto dan Kabupaten Gowa.

Wilayah Kabupaten Takalar terdiri dari 9 (sembilan) Kecamatan masingmasing:

Manggarabombang,

(2) Kecamatan

Mappakasunggu, (3), Kecamatan

Polombangkeng Selatan, (4) Kecamatan

Polombangkeng Utara, (5) Kecamatan

Galesong Selatan, (6) Kecamatan

Galesong Utara, (7) Kecamatan
Pattalassang, (8) Kecamatan Galesong, dan (9) Kecamatan Sanrobone.

Topologi wilayah Kabupaten Takalar terdiri dari pantai, daratan dan perbukitan. Di bagian barat adalah daerah pantai dan dataran rendah dengan kemiringan 0-3 derajat sedang ketinggian ruang bervariasi antara $0-25 \mathrm{~m}$, dengan batuan penyusun geomorfologi dataran didominasi endapan alluvial, endapan rawa pantai, batu gamping, terumbu dan tufa serta beberapa tempat batuan lelehan basal. Kabupaten Takalar dilewati oleh 4 buah sungai,yaitu Sungai Jeneberang, Sungai Jenetallasa, Sungai Pamukkulu dan Sungai Jenemarrung. Berdasarkan data Badan Pusat Statistik Kabupaten Takalar, pada tahun 2019 jumlah penduduk Kabupaten Takalar sebesar 298.688 jiwa. 


\section{Kontribusi Masing-masing Variabel}

\section{Pendapatan Asli Daerah}

Untuk mengetahui kontribusi dari masing-masing variabel pendapatan asli daerah terhadap pendapatan asli daerah pemerintah Kabupaten Takalar, maka tentunya kita membutuhkan data tentang besarnya penerimaan pemerintah daerah dari dari masing-masing variabel pendapatan asli daerah tersebut. Adapun data penerimaan Pemerintah daerah Kabupaten Takalar dari tahun 2010 sampai tahun 2020 dapat dilihat pada Tabel 3.

Tabel 3

Pendapatan Asli Daerah Kab. Takalar Tahun 2010-2020 (dalam jutaan rupiah)

\begin{tabular}{cccccc}
\hline Tahun & $\begin{array}{c}\text { Pajak } \\
\text { Daerah }\end{array}$ & $\begin{array}{c}\text { Retribusi } \\
\text { Daerah }\end{array}$ & $\begin{array}{c}\text { Hasil } \\
\text { Pengelolaan } \\
\text { Derah yang } \\
\text { Dipisahkan }\end{array}$ & $\begin{array}{c}\text { Lain-lain } \\
\text { PAD yang } \\
\text { sah }\end{array}$ & Total PAD \\
\hline 2010 & 2.093 & 19.044 & 3.650 & 8.370 & 33.157 \\
2011 & 2.390 & 21.030 & 3.650 & 8.128 & 35.198 \\
2012 & 3.507 & 21.366 & 5.081 & 5.066 & 35.021 \\
2013 & 3.581 & 22.418 & 4.589 & 3.072 & 33.660 \\
2014 & 5.505 & 31.181 & 4.850 & 3.097 & 44.633 \\
2015 & 15.928 & 12.256 & 6.350 & 3.437 & 97.971 \\
2016 & 16.108 & 14.226 & 7.325 & 67.456 & 105.115 \\
2017 & 16.760 & 4.532 & 8.993 & 81.395 & 111.680 \\
2018 & 18.459 & 4.755 & 10.209 & 127.994 & 161.417 \\
2019 & 21.214 & 5.201 & 10.209 & 104.197 & 140.821 \\
2020 & 49.450 & 3.833 & 8.964 & 98.610 & 160.857 \\
\hline Sumber: Direktorat Jenderal Perimbangan Kenangan Kementerian Kenangan Republik Indonesia
\end{tabular}

Sementara hasil perhitungan Daerah, hasil pengelolaan daerah yang kontribusi masing-masing variabel PAD dipisahkan, lain-lain PAD yang sah dapat dalam hal ini: pajak daerah, retribusi dilihat pada tabel 4. 
Tabel 4

Kontribusi Masing Variabel Pendapatan Asli Daerah terhadap Pendapatan Asli daerah Tahun 2010-2020 (dalam persen)

\begin{tabular}{cccccc}
\hline Tahun & $\begin{array}{c}\text { Pajak } \\
\text { Daerah }\end{array}$ & $\begin{array}{c}\text { Retribusi } \\
\text { Daerah }\end{array}$ & $\begin{array}{c}\text { Hasil } \\
\text { Pengelolaan } \\
\text { Derah yang } \\
\text { Dipisahkan }\end{array}$ & $\begin{array}{c}\text { Lain-lain } \\
\text { PAD yang } \\
\text { sah }\end{array}$ & Total PAD \\
\hline 2010 & 6,31 & 57,44 & 11,01 & 25,24 & 100 \\
2011 & 6,79 & 59,75 & 10,37 & 23,09 & 100 \\
2012 & 10,01 & 61,01 & 14,51 & 14,47 & 100 \\
2013 & 10,64 & 66,60 & 13,63 & 9,13 & 100 \\
2014 & 12,33 & 69,86 & 10,87 & 6,94 & 100 \\
2015 & 16,26 & 12,51 & 6,48 & 64,75 & 100 \\
2016 & 15,32 & 13,53 & 6,97 & 64,17 & 100 \\
2017 & 15,01 & 4,06 & 8,05 & 72,88 & 100 \\
2018 & 11,44 & 2,95 & 6,32 & 79,29 & 100 \\
2019 & 15,06 & 3,69 & 7,25 & 73,99 & 100 \\
2020 & 30,74 & 2,38 & 5,57 & 61,30 & 100 \\
\hline
\end{tabular}

Sumber: Data diolah, 2021

Tabel 4 memperlihatkan kepada kita, hasil perhitungan tentang kontribusi masing-masing variabel pendapatan asli daerah terhadap pendapatan asli daerah Kabupaten Takalar. Hasil perhitungan menunjukkan bahwa variabel Pajak Daerah, pada tahun 2010 sampai tahun 2011 kontribusi pajak daerah terhadap pendapatan asli daerah relatif kecil yaitu kurang dari 10 persen, namun secara perlahan kontribusi pajak daerah terhadap pendapatan asli daerah cenderung naik dari tahun ke tahun sehingga kontribusi pajak daerah terhadap pendapatan asli daerah pada tahun 2020 menjadi 30,74 persen.
Sementara itu kontribusi variabel retribusi daerah terhadap pendapatan asli daerah dari di Kabupaten Takalar, cenderung menurun dari ke tahun. Hasil perhitungan menunjukkan bahwa kontribusi retribusi daerah pada tahun 2010 sebesar 57,44 persen, selanjutnya naik selama 5 tahun berturut menjadi 69,86 persen pada tahun 2014, akan tetapi setelah itu penerimaan pemerintah daerah dari retribusi daerah cenderung menurun tajam, sehingga kontribusinya terhadap pendapatan asli daerah juga mengalami penurunan yang sangat tajam dan sampai pada tahun 2020, kontribusi retribusi daerah terhadap pendapatan asli daerah 
hanya sebesar 2,38 persen. Sejalan dengan retribusi daerah, kontribusi hasil pengelolaan daerah yang dipisahkan terhadap pendapatan asli daerah dari di Kabupaten Takalar juga mengalami tren menurun pada tahun 2010 kontribusi hasil pengelolaan daerah yang dipisahkan terhadap pendapatan asli daerah sebesar 11,01 persen, kemudian pada tahun 2011 turun menjadi 10,37 persen dan akhirnya pada tahun 2020 kontribusi hasil pengelolaan daerah yang dipisahkan terhadap pendapatan asli daerah menjadi 5,57 persen.

Pada sisi lain itu kontribusi variabel lain-lain PAD yang sah terhadap pendapatan asli daerah dari di Kabupaten Takalar dari tahun 2010 sampai tahun 2020 cenderung meningkat dari ke tahun.

Pada tahun 2010 kontribusi variabel lainlain PAD yang sah terhadap pendapatan asli daerah hanya sebesar, 25,24 kemudian mengalami penurunan selama empat tahun berturut-turut, sampai tahun 2014, akan tetapi pada tahun 2015 kembali mengalami peningkatan yang cukup besar sampai mencapai 64,75 persen, dan terus meningkat sampai pada tahun 2018 dengan kontribusi sebesar 79,29, akan tetapi pada tahun 2019 dan 2020 kembali mengalami penurunan dengan kontribusi masing-masing sebesar 73,99 persen dan 61,30 persen.

\section{Kontribusi Pendapatan Asli Daerah} terhadap Penerimaan Pemerintah

\section{Daerah}

Untuk mengetahui kontribusi pendapatan asli daerah terhadap total penerimaan daerah, maka perlu mengetahui besarnya penerimaan pemerintah daerah. Berdasarkan UndangUndang No.33 tahun 2004 tentang Perimbangan Keuangan antara Pemerintah Pusat dan Pemerintahan Daerah, bahwa Penerimaan pemerintah daerah pada dasarnya terdiri atas (1) Pendapatan asli daerah (PAD), (2) dana perimbangan, yang terdiri atas; dana bagi hasil (DBH), dana alokasi umum (DAU), dana alokasi khusus (DAK), dan (3) Lain-lain pendapatan daerah yang sah. Adapun penerimaan pemerintah daerah Kabupaten Takalar dalam tahun 2010-2020 dapat dilihat pada tabel 5 . 
Buyung Romadhoni dkk, Kontribusi Pendapatan Asli Daerah

Tabel 5

Pendapatan Kab. Takalar tahun 2010-2020 (dalam jutaan rupiah)

\begin{tabular}{ccccccc}
\hline Tahun & PAD & DBH & DAU & DAK & $\begin{array}{c}\text { Lain-lain } \\
\text { Pendapatan } \\
\text { yang Sah }\end{array}$ & $\begin{array}{c}\text { Total } \\
\text { Pendapatan }\end{array}$ \\
\hline 2010 & 33.157 & 23.000 & 304.060 & 43.478 & 21.400 & 425.096 \\
2011 & 35.198 & 23.085 & 334.735 & 43.637 & 63.854 & 500.510 \\
2012 & 35.021 & 26.686 & 409.281 & 46.836 & 84.113 & 601.937 \\
2013 & 33.660 & 26.686 & 479.074 & 48.957 & 88.761 & 677.138 \\
2014 & 44.633 & 22.818 & 565.195 & 64.133 & 110.307 & 807.086 \\
2015 & 97.971 & 20.306 & 554.136 & 62.688 & 173.204 & 908.306 \\
2016 & 105.115 & 20.306 & 597.986 & 206.335 & 251.194 & 1.180 .936 \\
2017 & 111.680 & 20.974 & 597.986 & 190.258 & 107.969 & 1.028 .867 \\
2018 & 161.417 & 18.925 & 595.467 & 274.879 & 160.008 & 1.210 .696 \\
2019 & 140.821 & 19.969 & 631.471 & 225.829 & 155.726 & 1.173 .816 \\
2020 & 160.857 & 15.569 & 636.229 & 197.642 & 133.425 & 1.143 .722 \\
\hline \multicolumn{5}{l}{ Sumber: Direktorat Jenderal Perimbangan Keuangan Kementerian Kenangan Republik Indonesia }
\end{tabular}

Berdasarkan Tabel 5, maka kita dapat rasio kontribusi. Adapun hasil perhitungan menghitung kontribusi pendapatan asli kontribusi PAD dan masing-masing daera (PAD) pemerintah Kabupaten variabel pendapatan daerah dapat dilihat Takalar, dengan menggunakan rumus pada tabel 6.

Tabel 6

Kontribusi PAD terhadap Pendapatan Daerah Kabupaten Takalar tahun 2010-2020 (dalam jutaan rupiah)

\begin{tabular}{ccccccc}
\hline Tahun & PAD & DBH & DAU & DAK & $\begin{array}{c}\text { Lain-lain } \\
\text { Pendapatan } \\
\text { yang Sah }\end{array}$ & $\begin{array}{c}\text { Total } \\
\text { Pendapatan }\end{array}$ \\
\hline 2010 & 7,80 & 5,41 & 71,53 & 10,23 & 5,03 & 100 \\
2011 & 7,03 & 4,61 & 66,88 & 8,72 & 12,76 & 100 \\
2012 & 5,82 & 4,43 & 67,99 & 7,78 & 13,97 & 100 \\
2013 & 4,97 & 3,94 & 70,75 & 7,23 & 13,11 & 100 \\
2014 & 5,53 & 2,83 & 70,03 & 7,95 & 13,67 & 100 \\
2015 & 10,79 & 2,24 & 61,01 & 6,90 & 19,07 & 100 \\
2016 & 8,90 & 1,72 & 50,64 & 17,47 & 21,27 & 100 \\
2017 & 10,85 & 2,04 & 58,12 & 18,49 & 10,49 & 100 \\
2018 & 13,33 & 1,56 & 49,18 & 22,70 & 13,22 & 100 \\
2019 & 12,00 & 1,70 & 53,80 & 19,24 & 13,27 & 100 \\
2020 & 14,06 & 1,36 & 55,63 & 17,28 & 11,67 & 100 \\
\hline
\end{tabular}


Tabel 6 menunjukkan bahwa sampai dengan tahun 2020 pendapatan darah masih didominasi oleh dana transfer dan pemerintah pusat khususnya dana alokasi umum (DAU) yang memberi kontribusi sampai di atas 50 persen dari total penerimaan pemerintah daerah Kabupaten Takalar, disusul dana bagi hasil yang memberikan kontribusi juga cukup tinggi sampai mencapai 17,28 persen pada tahun 2020. Kondisi ini menunjukkan bahwa tingkat kemandirian keuangan pemerintah daerah kabupaten Takalar relatif masih sangat rendah. Dalam arti bahwa pemerintah daerah Kabupaten Takalar, sebagian besar penerimaan daerahnya tergantung dari pemerintah pusat dalam membiayai Anggaran Pendapatan dan Belanja Daerahnya (APBD).

Kalau kita mencermati dengan baik, tentang kontribusi pendapatan asli daerah terhadap total penerimaan daerah Kabupaten Takalar, tentu kita dapat mengatakan bahwa PAD Kabupaten Takalar, memiliki kontribusi yang relatif kecil terhadap total penerimaan daerah. Meskipun demikian secara perlahan kontribusi PAD terhadap total penerimaan pemerintah daerah mengalami peningkatan yang cukup besar, dimana pada tahun 2010 kontribusi PAD terhadap total pendapatan daerah hanya sebesar 7,80 persen, namun secara perlahan mengalami kenaikan sehingga pada tahun 2020 kontrubusi PAD terhadap total penerimaan pemerintah daerah Kabupaten Takalar mencapai sebesar 14,06 persen.

\section{KESIMPULAN}

Hasil penelitian menunjukkan bahwa Pajak daerah dan lain-lain PAD yang sah, adalah dua variabel pendapatan asli daerah Kabupaten Takalar yang memiliki kontribusi yang cukup besar dan cenderung mengalami peningkatan dari tahun ke tahun dalam memberikan kontribusi terhadap pendapatan asli daerah. Sementara dua variabel lainya yaitu retribusi daerah dan hasil pengelolaan daerah yang dipisahkan memiliki kontribusi yang relatif kecil terhadap pendapatan asli daerah Kabupaten Takalar dalam beberapa tahun terakhir dan cenderung mengalami penurunan.

Hasil penelitian juga menunjukkan bahwa total penerimaan pemerintah daerah kabupaten Takalar, masih didominasi oleh penerimaan dari dana transfer pemerintah pusat terutama, dana alokasi umum (DAU) yang masingmasing memberi kontribusi di atas 50 
persen dari total penerimaan pemerintah daerah. Sementara pendapatan asli daerah memiliki kontribusi yang relatif masih kecil, akan tetapi secara perlahan, walaupun berfluktuasi namun cenderung mengalami peningkatan, dan sejak tahun 2017 kontribusi PAD terhadap total penerimaan pemerintah daerah Kabupaten Takalar sudah konsisten di atas 10 persen. Oleh karena retribusi daerah dan hasil pengelolaan daerah yang dipisahkan memiliki kontribusi yang relatif kecil terhadap pendapatan asli daerah Kabupaten Takalar dalam beberapa tahun terakhir, seyogyanya pemerintah daerah Kabupaten Takalar perlu melakukan kajian secara mendalam tentang faktorfaktor yang menyebabkan penerimaan PAD dari retribusi daerah dan hasil pengelolaan daerah yang dipisahkan mengalami penurunan. Untuk lebih meningkatkan kontribusi Pendapatan Asli daerah terhadap total penerimaan daerah kabupaten Takalar, maka pemerintah daerah perlu melakukan kajian secara mendalam dalam upaya untuk menggali segala potensi untuk meningkatkan penerimaan dari pendapatan asli daerah tanpa menimbulkan biaya ekonomi tinggi (high cost economy), disamping itu perlu usaha untuk menciptakan iklim usaha yang sehat dalam upaya untuk menarik para pengusaha untuk menanamkan modal di Kabupaten Takalar.

\section{DAFTAR PUSTAKA}

Aji B.P. I K.Kirya, G.P.A.J.sila. (2015). "Analisis Sumber Pendapatan Asli Daerah (PAD) Dalam Pelaksanaan Otonomi Daerah Di Kabupaten Buleleng." e-Journal Bisma Universitas Pendidikan Ganesha 3: 1-13.

Akhmad, N.A. Achsani, M.Tambunan, S.A.Mulyo. (2013). The Impact of Fiscal Policy on the Regional Economy: Evidence from South Sulawesi,. Journal of Applied Sciences Research (Journal of Applied Sciences Research) 9, no. 4: 2463-2474.

Akhmad. 2014. "Dampak Pengeluaran Pemerintah Daerah Terhadap Kemiskinan Pada Sepuluh Kabupaten Di Provinsi Sulawesi Selatan." Seminar Nasional; Optimalisasi Hasil-Hasil Penelitian Dalam Menunjang Pembangunan Berkelanjutan. Makassar: Lembaga Penelitian UNM, 2015. 32-46.

Akhmad, B.Romadhoni, F. Diana. (2020). "Tingkat kemandirian keuangan pemerintah Pemerintah Daerah Kabupaten dan Kota di Provinsi Sulawesi Selatan." Journal of Accounting \& Financial Reporting 4, no. 1: 1-12.

Akhmad. (2019). Manajemen Keuangan Daerah Dalam Era Otonomi Daerah; Sebuah Kajian Teoritis Dan Empiris. Bogor: Azkiya Publishing. 
Badan Pusat Statistik . (2020) Kabupaten Takalar dalam Angka. Badan Pusat Statistik Kabupaten Takalar. Takalar.

Cullis, J.G. and P.R. Jones. (1992).Public Finance and Public Choice. Singapore.: McGrow Hill,

Direktorat Jenderal Perimbangan keuangan,. (2017). Modul Kerjasama Peningkatan Kapasitas Pengelolaan Keuangan Daerah; Akuntansi Keuangan Pemerintah Daerah. Jakarta: Direktorat Jenderal Perimbangan Keuangan, Kementerian Keuangan Republik Indonesia.

Firdausy C.M. (2017). Optimalisasi Kebijakan Penerimaan Daerah. Jakarta: Yayasan Pustaka Obor Indonesia.

Mardiasmo. (2009). Kebijakan Desentralisasi Fiskal di Era Reformasi: 2005-2008: Era Baru kebijakan Fiskal. Jakarta: Kompas.

Peraturan pemerintah RI No.12 Tahun 2019. Pengelolaan Keuangan Daerah. Jakarta: Pemerintah Republik Indonesia.

Sabilla K \& W.K.Jaya. (2014). "Pengaruh Desentralisasi Fiskal Terhadap Pertumbuhan Ekonomi Per Kapita Regional Di Indonesia." Jurnal Ekonomi dan Studi Pembangunan 15 , no. $1: 12-22$.

Safrianto S. (2017). "Pengaruh Desentralisasi Fiskal Terhadap Pertumbuhan Ekonomi Di Provinsi Aceh." Jurnal E-KOMBIS 3, no. 2 :60-67.
Samimi A.J at al. (2010) "Fiscal Decentralization and Economic Growth in Iran." Australian Journal of Basic and Applied Sciences 4, no. 11 : 5490-5495.

Savitri K.A.dkk. (2019). "Analisis Faktor Penyebab Dan Akibat Dari Ketidaktepatan Waktu Penyusunan Anggaran Pendapatan Dan Belanja Daerah Kabupaten Buleleng Tahun 2017." Jurnal Ilmiah Akuntansi dan Humanika 9, no. 1 : 59-71.

Stiglitz J.E and J.K.Rosengard. (2015). Economics of The Public Sector. New York: W. W. Norton \& Company, Inc.

UU No. 32 Tahun 2004. Tentang Pemerintahan Daerah. Jakarta. Pemerintah Republik Indonesia, 2004.

UU No.33 Tahun 2004. Tentang perimbangan keuangan antara pemerintah pusat dan pemerintahan daerah. Jakarta: Pemerintah Republik Indonesia, 2004.

UU No. 28 Tahun 2009. tentang Pajak Daerah Dan Retribusi Daerah. Jakarta: Pemerintah Republik Indonesia, 2009.

Yanti N. (2013). Analisis Perkembangan Pendapatan Asli Daerah Dalam Mendukung Pengelolaan Keuangan Daerah Kota Padang." Jurnal KBP 1, no. 3: 439-453. 